\title{
COMPARATIVE INVESTIGATION OF FISH (Carassius gibelio) TREATED BY OSMOTIC DEHYDRATION IN MOLASSES AT DIFFERENT TEMPERATURES
}

\author{
Jasmina M. Gubić*, Dragana V. Plavšić, Ljubiša Ć. Šarić, Ana O. Varga, Ivana S. Čabarkapa,
} Bojana V. Filipčev, Olivera D. Šimurina

University of Novi Sad, Institute of Food Technology, 21000 Novi Sad, Bulevar cara Lazara 1, Serbia

\author{
${ }^{*}$ Corresponding author: \\ Phone: +381214853837 \\ Fax: +38121450725 \\ E-mail address: jasmina.gubic@fins.uns.ac.rs
}

\begin{abstract}
Different working temperatures were tested in order to confirm their effects on the quality of fish after osmotic dehydration. Microbiological profile and chemical content in fish were investigated, before and after osmotic treatment in sugar beet molasses solutions. Based on results it was concluded that molasses as hypertonic solution had great influence on the quality of the final product. The fat content decreased by $1.5 \%$ in sugar beet molasses solution at different temperatures $\left(20{ }^{\circ} \mathrm{C}\right.$ and $50{ }^{\circ} \mathrm{C}$ ). The average percentages of fish sugar showed a significant increase during osmotic dehydration at the two temperatures. Osmotic dehydration treatment had great impact on nutritional improvement of fish meat, especially on the mineral composition. Results indicated that the process of osmotic dehydration with sugar beet molasses is hygienically safe. Using sugar beet molasses as an alternative medium in osmotic dehydration opens new opportunities for innovation in dehydrated products.
\end{abstract}

Key words: osmotic dehydration, fish, sugar beet molasses

\section{INTRODUCTION}

One of the potential preservation techniques in production of products with low water content and improved nutritional, sensorial and functional properties is osmotic treatment. Osmotic dehydration, also called "dehydration-impregnation by soaking" (Raoult-Wack et al., 1991), is widely employed to remove water from pieces of meat by immersing them in a relatively concentrated aqueous solution of sugar and/or salt without any phase change. This process is mainly used for the partial removal of water, but it also leads to the penetration of solute into the product and the leaching of some natural solutes (sugars, minerals, etc.) from the product into the soaking solution. The main advantages of osmotic treatment are water removal in liquid form, usage of mild temperatures, reuse of the osmotic solution, improvement of the texture and color, no chemical pretreatment, energy efficiency, providing a stable and quality product (Della Rosa and Giroux, 2001; Pezo et al., 2013). Investigations on the effect of the process of osmotic dehydration of pork meat in molasses on micro-biological profile have shown that intermediate, osmodehydrated products had reduced number of present microorganisms, improved mi- 
crobiological profile, and it was adequate food material for the final technological procedures of production (Filipović et al., 2012; Nićetin et al., 2012).

Sugar beet molasses can be used as osmotic agent due to high content of solids and liquid aggregate state (Filipčev et al., 2008). Sugar beet molasses is an excellent medium for osmotic dehydration, primarily due to the high solid content (around $80 \%$ ) and specific nutrient content: $51 \%$ saccharose, $1 \%$ rafinose, $0.25 \%$ glucose and fructose, $5 \%$ proteins, $6 \%$ betaine, $1.5 \%$ nucleosides, purine and pyramidine bases, organic acids and bases, which subsequently results in high osmotic pressure of the solution (Mišljenović et al., 2008). From nutrient point of view, an important advantage of sugar beet molasses, as hypertonic solution, is enrichment of the food material in minerals and vitamins, which penetrate from molasses to the meat tissue (Filipović et al., 2012). In molasses, calcium, potassium and iron are present in substantial amounts although their contents vary over wide ranges (Šimurina et al., 2012). It is especially important to note that minerals in molasses are dissolved and that potassium is dominant with a share of $75 \%$ (by weight) of total cations (Šušić et al., 1989).

Temperature is one of the most important variables affecting the kinetic of mass transfer during osmotic dehydration. Rahman and Lamb (1990) have noted that at high temperatures, solute does not diffuse readily through the cell membrane as well as water, and the osmotic balance is achieved primarily through flow of water from the cells, which leads to a reduced solution in the dehydrated material. Higher temperature reduces the viscosity of the osmotic medium, allowing faster water loss and higher mass transfer (Tortoe, 2010).

The gibel carp (Carassius gibelio) is one of the dominant species in stagnant and slow-running waters and may change the flow of nutrients in the entire ecosystem (Paulovits et al., 1998). Fish meat is very important because of its unique composition and hence considered quality food for human consumption. Generally, $C$. gibelio is only freshly consumed. There are not many processing techniques except smoking (Izci, 2010).

The aim of the study presented in this paper was to examine the influence of sugar beet molasses solution at two different temperatures on nutritional composition and microbiological profile of the fresh fish meat.

\section{MATERIAL AND METHODS}

\section{Sample and osmotic solution preparation}

Carassius gibelio samples were purchased at a local market in Novi Sad (Serbia) and stored at $4{ }^{\circ} \mathrm{C}$ until use. Prior to the treatment, all working areas and tools were thoroughly washed, cleaned and disinfected with pharmaceutical ethanol $(70 \% \mathrm{v} / \mathrm{v})$. The fish meat was cut into cubes, dimensions of about $1 \times 1 \times 1 \mathrm{~cm}$, using a sharp knife.

Dry matter content of the fresh and treated samples was determined by drying at $105^{\circ} \mathrm{C}$ for $24 \mathrm{~h}$ in a heat chamber (Instrumentaria Sutjeska, Serbia) until constant weight after which they were minced and powdered for further analysis.

For the preparation of osmotic solution, commercially available sugar beet molasses from sugar factory Pećinci, Serbia, was used and its chemical composition is shown in Table 1. Chemical analyses of sugar beet molasses were performed according to AOAC methods (AOAC, 1984). Mineral content of molasses was determined by atomic absorption spectrometry with an atomic spectrometer "Varian", model "Spectra 10". Molasses used in the experiment was diluted to $80 \%$ of solids content.

\section{Osmotic dehydratation treatment}

The fish meat cubes were immersed in hypertonic solution (sugar beet molasses). The ratio of raw material and hypertonic solution was $1: 5$, and the immersion time lasted for 5 hours. Osmotic dehydration was carried out at atmospheric pressure and two temperatures of $20^{\circ} \mathrm{C}$ and $50^{\circ} \mathrm{C}$. Osmotic dehydration is conducted in a thermostat. After the treatment, the samples were taken out from osmotic solutions to be lightly washed with water and gently blotted with absorbent paper to remove excessive water. 
Table 1.

Chemical composition and characteristics of sugar beet molasses

\begin{tabular}{lc}
\hline Composition & \\
\hline Total solids,\% & 87.04 \\
Protein,\% & 10.38 \\
Sugar,\% & 52.32 \\
$\mathrm{Ca}, \mathrm{g} / \mathrm{kg}$ & 4.80 \\
$\mathrm{~K}, \mathrm{~g} / \mathrm{kg}$ & 22.11 \\
$\mathrm{Na}, \mathrm{g} / \mathrm{kg}$ & 3.18 \\
$\mathrm{Mg}, \mathrm{g} / \mathrm{kg}$ & 0.26 \\
$\mathrm{Fe}, \mathrm{g} / \mathrm{kg}$ & 0.10 \\
\hline
\end{tabular}

\section{Analytical procedures}

Chemical analyses of fresh and dehydrated fish were performed according to AOAC methods (AOAC, 2000). Water activity (aw) of the osmotically dehydrated samples was measured using a water activity measurement device (TESTO 650, Germany) with an accuracy of \pm 0.001 at $25{ }^{\circ} \mathrm{C}$. Determination of the total number of bacteria, Escherichia coli, coagulase positive staphylococci and sulphite reducing clostridia was done according to SRPS EN ISO 4833 (2008); SRPS ISO 16649-2 (2008); SRPS EN ISO 6888-1 (2003); SRPS ISO 15213 (2003). All analyses were performed in triplicates and results presented as mean values.

\section{Statistical analysis}

Analysis of variance and Duncan's multiple range tests were performed using the software package Statistica 10 for Windows, Stat Soft, Tulsa, Oklahoma, USA, 2009. Differences were considered significant at $p<0.05$.

\section{RESULTS AND DISCUSSION}

The average $a_{w}$ values and standard deviations of the fresh and dehydrated fish meat in sugar beet molasses are shown in Table 2. Increasing temperature from $20{ }^{\circ} \mathrm{C}$ to $50{ }^{\circ} \mathrm{C}$ led to the intensification of mass transfer between fish tissue and sugar beet molasses and a reduction in tissue $a_{w}$ values. The $a_{w}$ levels reached in fish after the process of osmotic dehydration at both working temperatures were smaller than the limiting value for $a_{w}$ growth of most microorganisms (Huang and Nip, 2001; Feiner, 2006), which indicates a positive effect of the osmotic treatment on the microbial profile of dehydrated fish.
Results of microbial analysis of fresh fish and fish treated by osmotic dehydration showed the absence of pathogenic bacteria, which indicated a good quality of fish meat. Tracking the change in the counts of the total bacteria can indicate the level of hygiene of the process. From Figure 1, the reduction of total number of bacteria in the fish dehydrated at both temperatures in comparison to the fresh fish can be observed. This result is due to the inhibitory effect caused by reduced $a_{w}$ value of the dehydrated fish meat and is in agreement with findings of Chabbouh et al. (2011). Also, the process temperature had a significant impact on the reduction of the total count of microorganisms in the samples. Results indicate that the process of osmotic dehydration of fish in sugar beet molasses is hygienically safe.

In our study, increasing trends were observed for $\mathrm{Na}, \mathrm{Mg}$ and Fe contents during the osmotic dehydration of fish at the two temperatures. The iron increase in dehydrated fish meat was very significant, since it is known that the iron absorption from meat usually spans between $15-20 \%$. Molasses provides very low level of iron, but it becomes increasingly soluble with an increase in temperature (Valclavik et al., 2007). This implies the significant improvement in the nutritional profile of meat as food (Higgs, 2000). The temperatures did not significantly influence the change in potassium content during osmotic dehydration. Although sugar beet molasses is rich in potassium, the viscosity of molasses falls at a given temperature.

With respect to viscosity behavior of molasses, $\mathrm{K}^{+}$ions raise the viscosity, while $\mathrm{Ca}^{2+}$ lowers it (Olbrich, 1963). The content of $\mathrm{Ca}$ was greater in the samples treated 
Table 2.

Average water activity (aw) values and standard deviation of the fresh and dehydrated fish

\begin{tabular}{lcc}
\hline Sample & $\mathbf{a}_{\mathrm{w}} / \mathbf{2 0}{ }^{\circ} \mathbf{C}$ & $\mathbf{a}_{\mathrm{w}} / \mathbf{5 0} \mathbf{0}^{\circ} \mathbf{C}$ \\
\hline Fresh fish & $0.944 \pm 0,007^{\mathrm{a}}$ & $0.944 \pm 0,007^{\mathrm{a}}$ \\
Fish dehydrated in sugar beet & $0.846 \pm 0,023^{\mathrm{b}}$ & $0.833 \pm 0,009^{\mathrm{c}}$ \\
molasses & &
\end{tabular}

Results are given as mean \pm standard deviation $(n=3)$; a,b,c - data followed by different letters indicate statistical difference $(\mathrm{p}<0.05)$

Table 3.

Chemical and mineral composition of fresh and osmotic dehydrated fish in sugar beet molasses

\begin{tabular}{lccc} 
Parameter & Fresh fish & $\begin{array}{c}\text { Dehydrated fish in } \\
\text { sugar beet molasses } \\
\left(\mathbf{t}=\mathbf{2 0} 0^{\circ} \mathbf{C}\right)\end{array}$ & $\begin{array}{c}\text { Dehydrated fish in sugar } \\
\text { beet molasses } \\
\left(\mathbf{t}=50^{\circ} \mathbf{C}\right)\end{array}$ \\
\hline Total solids,\% & $97.55^{\mathrm{a}} \pm 0.19$ & $98.52^{\mathrm{b}} \pm 0.59$ & $98.33^{\mathrm{b}} \pm 0.02$ \\
Protein,\% DM & $57.59^{\mathrm{a}} \pm 0.29$ & $60.16^{\mathrm{b}} \pm 0.31$ & $50.40^{\mathrm{c}} \pm 0.47$ \\
Fat,\% DM & $22.64^{\mathrm{a}} \pm 0.41$ & $14.50^{\mathrm{b}} \pm 0.22$ & $14.58^{\mathrm{b}} \pm 0.14$ \\
Sugar,\% DM & $0.66^{\mathrm{a}} \pm 0.04$ & $17.53^{\mathrm{b}} \pm 0.66$ & $22.01^{\mathrm{c}} \pm 0.20$ \\
$\mathrm{Ca}, \mathrm{g} / \mathrm{kg} \mathrm{DM}$ & $16.42^{\mathrm{ab}} \pm 0.62$ & $15.50^{\mathrm{a}} \pm 0.30$ & $17.43^{\mathrm{b}} \pm 0.18$ \\
$\mathrm{~K}, \mathrm{~g} / \mathrm{kg} \mathrm{DM}$ & $17.02^{\mathrm{a}} \pm 0.84$ & $16.24^{\mathrm{a}} \pm 0.08$ & $16.70^{\mathrm{a}} \pm 0.31$ \\
$\mathrm{Na}, \mathrm{g} / \mathrm{kg} \mathrm{DM}$ & $6.71^{\mathrm{a}} \pm 0.27$ & $7.08^{\mathrm{b}} \pm 0.12$ & $7.61^{\mathrm{b}} \pm 0.25$ \\
$\mathrm{Mg}, \mathrm{g} / \mathrm{kg} \mathrm{DM}$ & $0.77^{\mathrm{a}} \pm 0.02$ & $0.91^{\mathrm{b}} \pm 0.02$ & $1.50^{\mathrm{c}} \pm 0.01$ \\
$\mathrm{Fe}, \mathrm{g} / \mathrm{kg} \mathrm{DM}$ & $0.26^{\mathrm{a}} \pm 0.01$ & $0.30^{\mathrm{b}} \pm 0.01$ & $0.55^{\mathrm{c}} \pm 0.06$ \\
$\mathrm{Hg}, \mathrm{mg} / \mathrm{kg} \mathrm{DM}$ & $0.02^{\mathrm{a}} \pm 0.02$ & $0.01^{\mathrm{b}} \pm 0.01$ & $0.01^{\mathrm{b}} \pm 0.01$ \\
\hline
\end{tabular}

Results are given as mean \pm standard deviation $(n=3)$; DM - dry matter basis

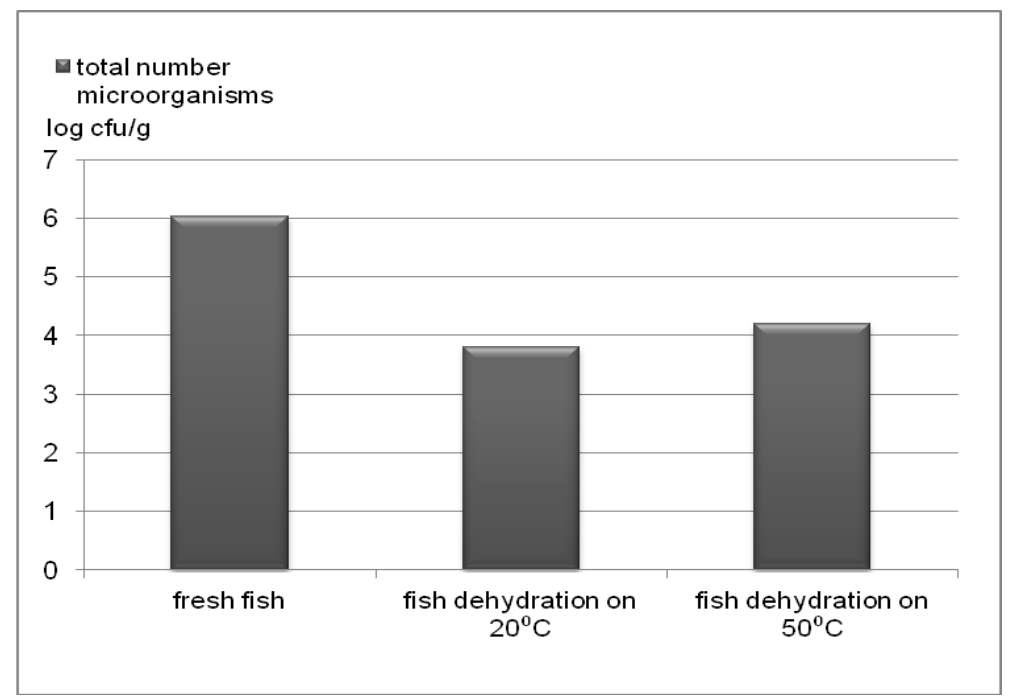

Figure1. The dynamics of change of total number microorganisms content in fish meat during osmotic treatment

at higher temperature $\left(50^{\circ} \mathrm{C}\right)$. Osmotic dehydration of fish in sugar beet molasses at both temperatures significantly affected the content of mercury in muscle tissue by decreasing half of its initial content.

\section{CONCLUSIONS}

Based on the results of analyses carried out at two working temperatures, it can be concluded that sugar beet molasses exhibited certain advances when applied as a hypertonic solution in the process of osmotic dehydration of fish. The microbiological profile of dehydrated fish at two temperatures confirmed that osmotic dehydration is a microbiologically safe process. Osmotic dehydration treatment had a great impact on the nutritional impro- 
vement of fish meat, especially its mineral composition. Osmotic dehydration in sugar beet molasses can be used as a pretreatment for many processes in order to improve the functional properties of fish, without a significant decrease in nutritive value of the product.

\section{ACKNOWLEDGEMENTS}

This paper is a result of the research within the project supported by the Ministry of Education, Science and Technological Development of the Republic of Serbia, TR-31055, 2011-2014.

\section{REFERENCES}

1. Association of Official Analytical Chemists (A.O.A.C.) (1984). Official and Tentative Methods of Analysis. 14th ed., Washington, DC, USA.

2. Association of Official Analytical Chemists (A.O.A.C.) (2000). Official and Tentative Methods of Analysis. 17th ed., Washington, DC, USA.

3. Chabbouh, M., Hajj, W., Hadj S.A., Faraht, A., Bellaghas, S., Sahli, A. (2011). Combined effect of osmotic dehydration and connective air drying of Kaddid meats: Kinetics and quality, Drying Technology, 1571-1579.

4. Della Rosa, M., Giroux, F. (2001). Osmotic treatments and problems related to solution management. Journal of Food Engineering, 49, 223-236.

5. Feiner, G. (2006). Meat products handbook, Practical science and technology, Woodhead Publishing Limited, Cambridge, England.

6. Filipović, V., Ćurčić, B., Nićetin, M., Plavšić, D., Koprivca, G., Mišljenović, N. (2012). Mass transfer and microbiological profile of pork meat dehydrated in two different osmotic solutions. Hemijska Industrija, 66 (5), 743-748.

7. Filipčev, B., Lević, Lj., Pribiš, V., Kabić, D. (2008). Melasa šećerne repe kao pogodan hipertoničan rastvor za osmotski pred-tretman jabuke. XIII savetovanje o biotehnologiji, Zbornik radova, 323-329.

8. Higgs, J.D. (2000). An overview of the compositional changes in red meat over the last 20 years and how these have been achieved. Food Science and Technology Today, 14(1), 22-26.

9. Huang, T., Nip, W. (2001). Intermediate-Moisture Meat and Dehydrated Meat, In: Meat Science and Application, CRC Press.

10. Izci L. (2010). Utilization and Quality of Fish Fingers from Prussian Carp (Carassius gibelio Bloch, 1782), Pakistan Veterinary Journal, 30, 207-210.

11. Mišljenović, N., Koprivica, G., Lević, Lj., Petkova, M., Kuljanin, T. (2008). Mass Transfer during Osmotic Dehydration of Apple and
Carrot in Sugar Beet Molasses. Journal on Processing and Energy in Agriculture, 12, 211 $-214$.

12. Nićetin, M., Filipović, V., Ćurčić, B., Knežević, V., Plavšić, D., Pezo, L., Kuljanin, T. (2012). The Change in Microbiological Profile due to the Osmotic Dehydration of Pork Meat. Proceedings of the 6th Central European Congress on Food: CEFood 2012, 834-839.

13. Olbich, H. (1963). The molasses. Fermentation Technologist, Institut für Zuckerindustrie, Berlin (Germany).

14. Paulovits, G., Tatrai, I., Matyas, K., Korponai, J., Kovats, N. (1998). Role of Prussian carp (Carassius auratus gibelio Bloch) in the nutrient cycle of the Kis-Balaton Reservoir. International Review of Hydrobiology, 83, 467-470.

15. Pezo, L., Ćurčić, B., Filipović, V., Nićetin, M., Koprivica, G., Mišljenović, N., Lević, Lj. (2013). Artificial neural network model of pork meat cubes osmotic dehydration. Hemijska Industrija, 67 (3), 465-475.

16. Rahman M.S., Lamb J. (1990). Osmotic dehydration of pineapple. Journal of Food Science and Technology, 27, 150-152.

17. Raoult-Wack, A. L., Botz, O., Guilbert, S., Rios, G. (1991). Simultaneous water and solute transport in shrinking media, part I: Application to dewatering and impregnation soaking process analysis (osmotic dehydration), Drying Technology, 9, 589-612.

18. SRPS EN ISO 6888-1 (2003). Microbiology of food and animal feeding stuffs. Horizontal method for the enumeration of coagulase positive staphylococci (Staphylococcus aureus and other species)-Part1: Technique using Baird-Parker agar medium.

19. SRPS EN ISO 15213 (2003). Microbiology of food and animal feeding stuffs. Horizontal method for the enumeration of sulfite-reducing bacteria growing under anaerobic conditions.

20. SRPS EN ISO 4833 (2008). Microbiology of food and animal feeding stuffs. Horizontal method for the enumeration of microorganismsColony-count technique at 30 degrees $\mathrm{C}$.

21. SRPS ISO 16649-2 (2008). Microbiology of food and animal feeding stuffs. Horizontal method for the enumeration of $\beta$-glucuronidasepositive Escherichia coli - Part 2: Colony-count technique at $44{ }^{\circ} \mathrm{C}$ using 5-bromo-4-chloro-3indolyl $\beta$-D-glucuronide.

22. Šimurina, O., Ikonić, B., Jevtić-Mučibabić, R., Belović, M., Koprivica, G, Mišljenović, N. (2012). Application of response surface methodology in the development of specialty bread with sugar beet molasses, flax seed and vital wheat gluten, Food and Feed Research 39, 1121.

23. Šušić, S., Sinobad, V. (1989). Istraživanje u cilju unapređenja industrije šećera Jugoslavije, Hemijska industrija, 43 (1-2), 10-21.

24. Tortoe, C. (2010). A review of osmodehydration for food industry. African Journal of Food Science, 4, $303-324$. 
25. Vaclavik, V., Christian, E. W. (2007). Essentials of Food Science, Texsas, USA.

26. Vujadinović, D., Grujić, R., Tomović, V., Torbica, A. (2014). Effects of temperature and me- thod of heat treatment on miyofibrillar proteins of pork. Chem. Ind. and Chem. Engineering Quarterly, DOI: 10.2298/CICEQ121011023.

\section{КОМПАРАТИВНО ИСПИТИВАҢЕ РИБЕ (Carassius gibelio) ОСМОТСКОМ ДЕХИДРАТАЦИЈОМ У МЕЛАСИ НА РАЗЛИЧИТИМ TEMПEPATУPAMA}

Јасмина М. Губић*, Драгана В. Плавшић, Љубиша Ћ. Шарић, Ана О. Варга, Ивана С. Чабаркапа, Бојана В. Филипчев, Оливера Д. Шимурина

Универзитет у Новом Саду, Научни институт за прехрамбене технологије у Новом Саду, 21000 Нови Сад, Булевар цара Лазара бр. 1, Србија

Сажетак: Тестиране су различите радне температуре у циљу утврђивања њиховог утицаја на квалитет рибе након процеса осмотског сушења у раствору меласе шећерне репе. Анализиран је микробиолошки профил и нутритивни састав рибе, пре и после процеса осмотског сушења у раствору меласе шећерне репе. На основу добијених резултата, закључено је да је употреба хипертоничног раствора меласе имала велики утицај на квалитет финалног производа. Садржај масти смањен је око 1.5\% у дехидрираној риби на температурама $20{ }^{\circ} \mathrm{C}$ и $50{ }^{\circ} \mathrm{C}$. Средње вредности садржаја шећера значајно су повећане током осмотске дехидратације рибе на две температуре. Третман осмотске дехидратације имао је велики утицај на нутритивно побољшање меса рибе, посебно на минерални састав. Добијени резултати указују на то да је процес осмотске дехидратације са меласом шећерне репе хигијенски безбедан. Коришћење меласе шећерне репе, као алтернативног медијума за процес осмотске дехидратације, отвара нове могућности за иновације у дехидратацији производа.

Кључне речи: осмотска дехидратација, риба, меласа шећерне репе

Received: 20 August 2014

Accepted: 15 October 2014 